\title{
Empowerment of Extended Family and Local Institution To Prevent Divorce
}

\author{
Fachrina $^{1}$, Maihasni $^{2}$, Sri Meiyenti ${ }^{3}$ \\ \{fachrina_tanjung@yahoo.com ${ }^{1}$, maihasni@yahoo.co.id ${ }^{2}$, smeiyenti@yahoo.com ${ }^{3}$ \} \\ Department of Sociology Faculty of Social and Political Sciences. Universitas Andalas, Padang, \\ Indonesia
}

\begin{abstract}
The rise of divorce in society need to be analyzed and addressed properly. Indepth research in regards to prevention effort to develop a model of a divorce prevention strategy needs to be done to avoid widespread negative impacts in the community as it may weaken the social resilience of the community. Participatory approaches can solve it by empowering various elements within the local community (local institutions). Previous preliminary studies [1], it is known that the extended family and local institutions have the potential to prevent divorce. The Minangkabau community with the Matrilineal kinship system ideally provides immense space for extended families to play a role in various aspects of life. However, the role of extended families such as the existence of parents, inlaws, and mamak relatively not utilized functionally. Likewise with the existence of local institutions that exist in society, among others; LKAAM (Lembaga Kerapatan Adat Alam Minangkabau) or KAN (Kerapatan Adat Nagari) at Nagari level, and LPM (Lembaga Perberdayaan Masyarakat) and other formal institutions such as Majelis Taklim and Bundo Kanduang. For that purpose, this research is to develop efforts that can be done to empower the extended family and local institutions in preventing and solving the rampant divorce.
\end{abstract}

Keywords: Empowerment, Extended Family, Local Institution, Divorce Prevention.

\section{Introduction}

Divorce is the breaking of the marital bond between the married couple. Article 38 of the Law on Marriage No. 1 of the year 1974, states that marriage may be terminated due to death, divorce and the decision of the Court. The death divorce "cerai mati" is the dissolution of marriage due to death, while the ordinary divorce in the society known as "cerai talak" and "cerai gugat". Meanwhile, the marriage that breaks up based on the Court's decision is called marital cancellation.

The cause of divorce is very diverse, including dis-match, personal tension, domestic violence, polygamy, cheating, financial problems, underhand marriage, the age difference, and young marrieds. Moreover, the internal factors of the husband and wife including family intervention factors and social pressure and weak social control of society may also contribute to divorce [2]-[5].

Puslitbang Kehidupan Beragama of the Ministry of Religious Affairs stated that divorce rate, especially "gugat cerai" case in Indonesia is increasing. It increases by $52 \%$ percent in the last five years, i.e., 2010-2015 (kemenag.go.id). Of the two million marriages, 15-20 percent are divorced. West Sumatra registered itself as a province with the second highest number of divorce in Indonesia. If the average number of divorces in Indonesia is 200,000 pairs per year 
or 10 percent of marriage events, then in West Sumatera it reaches 6.325 or above 10 percent of marriage (harisinggalang.co.id).

However, the efforts should be made to prevent and overcome the divorce trend in society. The government through the Badan Penasihat Pembinaan Pelestarian Perkawinan (BP4) has tried to reduce the divorce rate by introducing the bride and groom course (Suscatin) as a provision in running the marriage and mediation of couples who will divorce. As well as, continue to socialize the program Gerakan Keluarga Sakinah (GKS) under the Director General of Islamic Community Guidance. However, the existence of BP4 is relatively unutilized, as well as mediation efforts undertaken by the Religious Courts of the divorced couple are said to be relatively ineffective, where the success rate is relatively small (Fachrina et al., 2017; Bahalwan, 2012).

These divorce prevention efforts should not be entirely left to the government, but also the involvement of the social institutions in society. Previous research finds extensive families such as the presence of parents, in-laws and mamak and local institutions; LKAAM or KAN at Nagari level, LPM, Majelis Taklim, Bundo Kanduang have potential in preventing divorce (Fachrina et al., 2013, 2017). It is necessary to strengthen the role of extended families and local institutions through empowerment. Efforts of empowerment are the way of development of things, which are from the state of helplessness to be useful to achieve a better life.

\section{Research Methodology}

This research is conducted by using qualitative research methods; the authors understand the object of research through the understanding of research subjects to the problems studied without being released from the context. The research subject was chosen purposively (purposive sampling), consisting of elements, which are divorced couple and extended family (parents and mamak), Kerapatan Adat Alam Minangkabau (LKAAM), Kerapatan Adat Nagari (KAN), Lembaga Pemberdayaan Masyarakat (LPM), Majelis Taklim and Bundo Kanduang. Since the level of analysis is placed in the local community, the individual (actor) who is made as the subject is not seen as not only himself but is considered and placed as an individual representing his group where data collection techniques used in this study are observation techniques and in-depth interviews. The data and information obtained from the research are interpreted qualitatively by combining the categories available to create descriptions based on relevant literature studies. Data analysis is done from the beginning of data collection in the field until the conclusion of several phenomena has been observed

The selected research location is an urban area in West Sumatera province namely Padang and Payakumbuh, where the community is assumed to have a variety of socioeconomic status which is relatively diverse and relatively high divorce rate compared to other regions.

\section{Result and Study}

From previous preliminary studies (Fachrina \& Eka Putra, 2013) on the potential of extended families and local institutions in divorce prevention, it is known that these two institutions to have such potential. This research explains that parents, mother's siblings (mamak) based on extensive experience and knowledge become an important role as a hightolerant figure "yang dianjuang tinggi dilambuak gadang, ditinggikan sarantiang dan didulukan 
salangkah", can give understanding and lesson or advice to nephew well before marriage and or during the marriage. Of course, wisdom and just attitude must be attached to their role as parents and ninik mamak. Parents and Mamaks can maximize their roles and responsibilities for nephews who have problems with marriage.

Every parent is happy when their children's family have a peaceful life ever after; therefore if there is a household problem, ideally parents will try to keep the marriage. The reality in this study the role of parents is limited to advise. It means that parents do not have a concrete step on how to help solve the problem of their child marriage as an effort to prevent divorce. Therefore, in order to realize the role of parent to prevent divorce actively, the first thing to do is to empower parents by providing knowledge and skills on how to create and maintain the harmony of marriage relationships and mechanisms for resolving domestic conflicts. Parents here have knowledge and skills from the experience of only regarding everyday household activity and problem. The advice or ways parents do to their children by what they have experienced might not necessarily match or succeed in the case of their child's marriage. Secondly, parents need to grow their awareness about their position as parents in the household or family of their children. How should parents be able to position themselves in the marriage of son or daughter in law where the should not be too involved in the affairs and issues of their child's household. BP4 can do counseling to empower parent roles. To date, BP4 only do a course of debriefing for the couple that is about to get married in order to live an ideal marriage life to reach sakinah family. Community institutions such as Majelis Taklim can also play a role in this.

As well as the existence of "mamak". In some divorce cases in the Minang community, the interviewees (KAN's management) acknowledged that there is a tendency now that mamak is not involved in the process of solving nephew marriages. Mamak has just been notified after the couple takes the divorce decision, so the mamak are relatively unable to do anything else to prevent the divorce.

In Minangkabau society marriage and divorce become the problem or affair of a relative whose decision depends on the consensus result of "ninik mamak" and family where a marriage that is not harmonious becomes the responsibility of the family (Navis, 1986). If husband and wife can not solve the argument and conflict between married couples in their marriage life, then the husband reported the problem to his wife's parents, then the wife's parents will discuss the problem with their child and or son-in-law. In this stage, if the problem can not be resolved, then the parent will report it to the "ninik mamak". Furthermore, "ninik mamak" with the closest relatives of both sides meet to discuss the best way to solve the marital problems of their nephew, to decide whether to divorce or not.

However, based on the results of this study, this ways tends not to be done in divorce decision making. In general, the decision to divorce by a married couple is the result of a limited discussion between husband and wife. The family is widely notified when the divorce decision has been taken. For this reason, efforts should be made to re-establish matrilineal kinship relations, especially the nephew relations, such as creating a legal umbrella for the role of mamak against nephews and improving indigenous knowledge of the mamak. Also sought the active role of extended families in providing guidance and supervision for the continuity of their nephew's marriage, among others by involving an extended family from the beginning in the process of marriage and divorce.

Kerapatan Adat Nagari (KAN) is the highest customary institution in Nagari, where the gathering of penghulu in Nagari is called "ninik mamak". In addition to addressing the issue of customary matters relating to sako (lineage) and pusako (inheritance), KAN can be expected to have a role in maintaining the continuity of marriage of a family in their Nagari, as KAN Koto 
Baru Balai Janggo Payakumbuh. As the best KAN in West Sumatra, this institution has been implementing efforts to prevent divorce in the community by conducting a bridal program for prospective brides (Catin). Moreover, KAN can act as a facilitator to carry out mediation between couples who will divorce before the involved parties take the divorce decision. The way out of the domestic crisis as a cause of divorce should be sought here by agreeing on several points by various parties so that peace can be pursued and divorce does not occur. The marriage dispute should ideally be at the level of the KAN court and not to the Religious Courts. In this case, the committee or the KAN members themselves should have the skills as facilitators and mediators. Education and training to be mediators can be made to KAN boards and members, as well as increasing their knowledge of religion, customs and marriage norms. Therefore, KAN does resolve not only disputes caused by the existence of debt obligations, inheritance, environmental pollution, and similar disputes (civil justice) but also divorce cases.

Moreover, there is also the Lembaga Pemberdayaan Masyarakat (LPM). One of the objectives of the establishment of LPM is to encourage, establish and empower the role of women in realizing family welfare. The leading causes of disharmony are related to economic factors, namely low income, and household economic management, becomes the source of contention that triggers a divorce. Family economic empowerment, especially at the grassroots, is needed. Income that increases directly or indirectly affects the welfare of the family which has implications for the creation of harmony within.

Empowerment of other institutions such as Bundo Kanduang and Majelis Taklim also needs to be done. The strength of Bundo Kanduang's institution in society indicated by the authority to organize the way of life of the Rumah gadang in harmony. Here women become the head of the Rumah Gadang. If there are cases in the Rumah Gadang, then the first settlement is done by Bundo Kanduang. The settlement is brought before ninik mamak within the community if Bundo Kanduang can not solve the problem. The existence of Bundo Kanduang as a recognized adat institution in Nagari government is to maintain the social order of families, households, and womenkind. The existence of this institution can be utilized in the effort to prevent divorce in society. Optimizing the role and function of this group in the dissemination of religious values and how to build a sakinah, mawaddah and warrahmah family as a provision for married couples in running a marriage and family.

\section{References}

[1] Bahalwan, Nizar, 2012. "Efektifitas Mediasi BP4 dan Pengadilan Agama di Kota Administratif Jakarta Timur". UIN Syarif Hidayatullah. Jakarta.

[2] Bakaruddin R dkk, 1998. "Faktor-Faktor Sosial Penyebab Perceraian di Sumatera Barat". Dalam Jurnal Pembangunan dan Perubahan Sosial Budaya No.5/1998 FISIP. Universitas Andalas.

[3] Fachrina \& Nini Anggraini, 2007. "Penyesuain Kembali Peran dan Hubungan Sosial Pasangan yang Bercerai". Laporan Penelitian Dosen Muda DIKTI. Lembaga Penelitian Unand. Padang.

[4] Fachrina \& Eka Putra, Rinaldi, 2013. Upaya Pencegahan Perceraian Berbasis Keluarga Luas dan Institusi Lokal dalam Masyarakat Minangkabau di Sumatera Barat. Jurnal Antropologi Vol. 34 No.2 Juli-Desember.

[5] Khairuddin, 1985. "Sosiologi Keluarga". Yogyakarta: Nurcahya IKAPI.

[6] Karim, Erna. 1999. "Pendekatan Perceraian dari Perspektif Sosiologi". Dalam Thromi, Bunga Rampai Sosiologi Keluarga. Jakarta: Yayasan Obor Indonesia.

[7] Navis, A.A, 1986. "Alam Terkembang Jadi Guru". Jakarta: PT Pustaka Grafitipers.

[8] Undang-Undang Nomor 1 Tahun 1974 Tentang Perkawinan Lembaran Negara Tahun 1974 Nomor 1

[9] http://hariansinggalang.co.id/perceraian-di-sumbar-di-atas-rata-rata-nasional/, diakses tanggal 12 Mei 2016 
